九州大学学術情報リポジトリ

Kyushu University Institutional Repository

Subgeneric Positions and Redescriptions of East Asian Andrena Preserved in Two U. S. Natural History Museums (Hymenoptera, Andrenidae)

Xu, Huan-li

Tadauchi, Osamu

https://doi.org/10.5109/2619

出版情報: ESAKIA. 37，pp.177-185，1997-09-30. Entomological Laboratory，Faculty of Agriculture, Kyushu University バージョン：

権利関係 : 


\title{
Subgeneric Positions and Redescriptions of East Asian Andrena Preserved in Two U. S. Natural History Museums (Hymenoptera, Andrenidae) ${ }^{1,2), 3 \text { ) }}$
}

\author{
Huan-Ii XU and Osamu TadauchI \\ Entomological Laboratory, Faculty of Agriculture, \\ Kyushu University, Fukuoka 812-8 1, Japan
}

\begin{abstract}
Six species of the genus Andrena described by Cockerell from China and Japan, which are preserved in the National Museum of Natural History, Smithsonian Institution, Washington D. C. and the American Museum of Natural History, New York, are examined. Three synonyms are newly recognized, Andrena praecociformis Cockerell and Andrena speculella Cockerell are synonymized with Andrenahebes Perez and Andrena melanospila Cockerell, respectively, in addition, Andrena(Simandrena) koma Hirashima is synonymized with Andrena delicatula Cockerell. Andrena (Leucandrena) melanospila, A. (Leucandrena) delicatula, A. (Taeniandrena) callopyrrha are redescribed and firstly given their subgeneric positions, $A$. (Melandrena) crassepunctata is redescribed and transferred from the subgenus Gymnandrena.

Key words: Taxonomy, Hymenoptera, Andrenidae, Andrena, Asia, types of US museums.
\end{abstract}

\section{Introduction}

Cockerell (1911, 1918, 1929, 1931a, 1931b) described eighteen new species of the genus Andrena from China and Japan. Some Japanese species were treated by Hirashima (1962-1966), but Andrena praecociformis Cockerell remained an undetermined species (Hirashima, 1965). In this paper, we recognize Andrenapraecociformis as a new synonym of Andrena hebes Perez. We also examined 5 type species described from China and recognize Andrena speculella Cockerell as new synonym of Andrena

1) Contribution from the Entomological Laboratory, Faculty of Agriculture, Kyushu University, Fukuoka (Ser. 5, No. 1).

2) This work was supported by a Grant-in-Aid for Scientific Research of an International Scientific Research Program from the Ministry of Education, Science, Sports and Culture, Japan (No.07041 144) (Head Investigator: 0. Tadauchi).

3) Results from the China-Japan Co-operative Study on "Studies on Systematics, Evolution and Biogeography of Asian Andrena (Hym., Apoidea, Andrenidae)" No. 6. 
melanospila Cockerell, in addition, A. (Simandrena) koma Hirashima is synonymized with A. delicaluta Cockerell. Andrena (Leucandrena) melanospila, A. (Leucandrena) delicatula and A. (Taeniandrena) callopyrrha are redescribed and firstly given their subgeneric positions, A. (Melandrena) crassepunctata is also redescribed and given the subgeneric position.

\section{Andrena (Euandrena) hebes Perez}

Andrena hebes Perez, 1905, Bull. Mus. d'Hist. Nat., Paris, 35 [female, Japan]; Cockerell, 1913, Ann. Mag. nat. Hist., (8)11: 154; Alfken, 1932, Mitt. Deut. ent. Ges., 3: 117 [female \& male]; Uéda, 1954, Trans. Shikou ent. Soc., 4: 50 [in list]: Yasumatsu, 1941, Peking nat. Hist. Bull., 15: 276 [in list].

Andrena (Euandrena) hebes: Hirashima, 1964, J. Fac. Agr., Kyushu Univ., 13: 46-49 [redescription, female \& male, Japan]; Hirashima, 1966, J. Fac. Agr., Kyushu Univ., 14: 109 [female in key], 119 [male in key]; Tadauchi \& Hirashima, 1984, Esakia, (22): 108 [female \& male, in key].

Andrena praecociformis Cockerell, 1911, Proc. U. S. nat. Mus., 40: 243 [male. Japan]; Cockerell, 1913, Ann. Mag. nat. Hist., 8( 11): 190 [male]; Yasumatsu, 1941. Peking nat. Hist. Bull., 15: 279 [in list]; Hirashima, 1965, J. Fac. Agr.. Kyushu Univ., 13: 516. New synonymy

Type material examined: Holotype male of Andrena praecociformis Cockerell, Nishigahara, Tokyo, Japan, No. 13530, U. S. N. M.

Remarks: The type of Andrena praecociformis Cockerell, 1911 has less black hairs on the face and the sides of propodeum, but it has the characteristics of A. hebes Perez. 1905 , such as the distinct malar space and the genital capsule with dorsal lobes of gonocoxites more elongate. So we decided $A$. praecociformis is a new synonym of $A$. hebes.

Distribution: Japan (Honshu, Sado Is., Shikoku, Kyushu).

Floral records: See Hirashima (1964).

Flight records: Female: mid March to late April. Male: mid March.

\section{Andrena (Leucandrena) melanospila Cockerell}

(Figs. 1-4)

Andrena melanospila Cockerell, 1918, Ann. Mag. nat. Hist., (9)2:48 1 [female. China]; Yasumatsu, 1941, Peking nat. Hist. Bull., 15: 278 [in list].

Andrena speculella Cockerell, 1931, Amer. Mus. Nov., (466): 12 [female, China]; Yasumatsu, 1941, Peking nat. Hist. Bull., 15: 280 [in list]; Wu, 1965. Econ. Insects China IX, Apoidea: 32 [China]. New synonymy

Redescription of the type of melanospila: Female: BL $10.0 \mathrm{~mm}$, WL $8.5 \mathrm{~mm}$.

Color: Flagellum reddish brown beneath; mandible almost reddened; wing membrane infumate, veins and pterostigma reddish brown; tibia1 spurs yellowish: posterior depressions of metasomal terga reddish brown. 

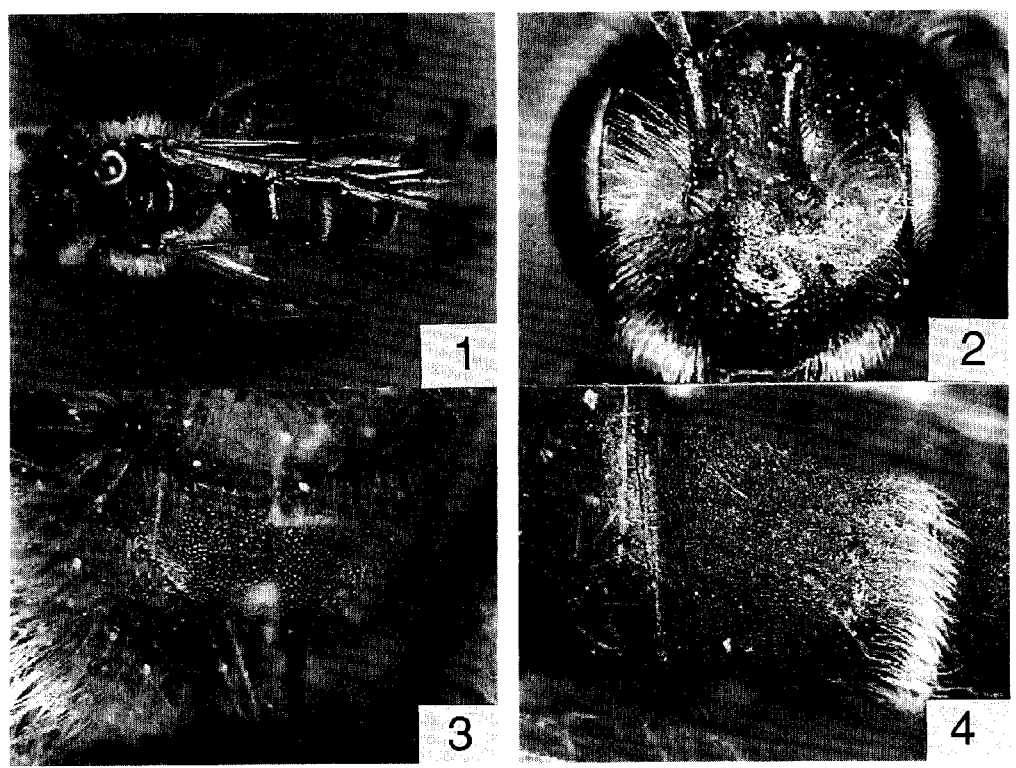

Figs. 1-4. Andrena (Leucandrena) melanospila Cockerell, 1: dorsal view of the whole body; 2: head in frontal view; 3: propodeum; 4: metasomal terga.

Pubescence: Hairs on head and thorax dense, dull whitish to bright brown: those on clypeus short $(200-250 \mu)$, sparser medially, denser at extreme angle area: those on vertex $(300-500 \mu)$, sparse, bright brown; those on genal area more or less dense, whitish: facial fovea brown. Hairs on mesoscutum $(400-500 \mu)$, bright brown posteriorly. paler anteriorly; those on scutellum and metanotum long, dense and yellowish: propodeal corbicula well developed with complete anterior fringes, without internal hairs: mesepisternum with long, whitish hairs; trochanteral floccus perfect, whitish; femoral floccus dense; tibial scopal hairs moderately long, simple, whitish in front, bright brown above. Hairs on metasomal terga scanty except $\mathrm{T}_{1-2}$ with long $(400-600 \mu)$, whitish hairs; $\mathrm{T}_{3-4}$ with short hairs at sides; $\mathrm{T}_{2-4}$ with complete white hair bands apically; caudal fimbria brown; $S_{2-4}$ with long white subapical fimbriae, $S_{5}$ with brown fimbria.

Structure: Head: HL / HW $=0.78$. HW $: \mathrm{MsW}: \mathrm{MtW}=3.0: 3.0: 3.2$. Vertex finely tessellate. OOD : POD : OCD = $0.6: 0.4: 0.2 . \mathrm{FL}_{1}<\mathrm{FL}_{2}+3, \mathrm{FL} ; !=$ FL3. Eyes with inner margins paralleled. Facial fovea slightly exceeding below a line at lower margins antennal fossae, broad, FVL $=1.1 \mathrm{~mm}, \mathrm{FVW}=0.5 \mathrm{~mm}$. Facial quadrangle broader than long (about $2.2: 2.0$ ). Clypeus smooth and shiny except weakly tessellate laterally. surface with broad, median longitudinal impunctate space, sparse $\mathrm{PP} \emptyset 20-40 \mu$, irregular in distribution, dense $\mathrm{PP} \phi 10 \mu$, IS $<0.5$ at extreme angle area, $\mathrm{CPL}=1.0 \mathrm{~mm}$. Process of labrum moderate, triangular, obtuse and convex apically. Lower paraocular area densely tessellate with close PP. Malar space linear. Genal area broader than eye. GW : $\mathrm{EW}=0.8: 0.6$, surface weakly tessellate posteriorly, smooth and shiny near eye with close PP. Mesosoma: Pronotum with distinct humeral angle and ridge, median longitudinal suture at anterior margin of dorsum obscure, surface densely tessellate. 
Mesoscutum shagreened anteriorly, finely tessellate at rest of area, with $\operatorname{PP} \emptyset 20 \mu$. IS $<1$, sparser medially. Scutellum smooth and shiny with $\mathrm{PP} \phi 20 \mu$, IS $<0.5$, irregular in distribution. Propodeal enclosure large, finely granulate all over: dorsal face weakly roughened. Mesepisternum shagreened by coarse tessellation. Metasoma: Metasomal terga strongly tessellate, impunctate; posterior depressions of terga narrow, well indicated. Pygidial plate U-shaped with raised triangular area. $\mathrm{S}_{2-5}$ densely tessellate with close PP except $S_{2-3}$ weakly tessellate basally, impunctate.

Type material examined: Holotype female of melanospila, Soochou, China (N. Gist Gee, 120), No. 23136, U. S. N. M.; Holotype female of speculella, Zi-ka-wei. Shanghai, China, 11. iv. 1925 (0. Piel).

Remarks: We found this species also distributed in Shanghai and Zhejiang Province. China. We will describe the male of this species in another paper.

Distribution: China (Shanghai, Jiangsu and Zhejiang Provs.).

Floral record: Rubus hirsutus.

Flight records: Female: late March to mid April.

\section{Andrena (Leucandrena) delicatula Cockerell}

(Figs. 5-8)

Andrena delicatula Cockerell, 1918, Ann. Mag. nat. Hist., (9)2: 481-482 [male, China]; Yasumatsu, 1941, Peking nat. Hist. Bull., 15: 275 [in list].

Andrena (Simandrena) koma Hirashima, 1952, Mushi, 24: 32 [female, Korea]; Tadauchi \& Lee, 1992, Esakia, (32): 51 [Korea]; Tadauchi \& Xu, 1995, Esakia, (35): 210 [China, Korea]. New synonymy

Redescription of the type: Male: BL $8.0 \mathrm{~mm}$, WL $7.0 \mathrm{~mm}$.

Color: Flagellum reddish brown beneath; mandible with apical third reddened: wing membrane infumate, veins and pterostigma reddish yellow; tibia1 spurs ochraceous: posterior depressions of metasomal terga dark ferruginous.

Pubescence: Hairs on head and thorax abundant, white to pale yellowish; those on clypeus long $(600-700 \mu)$, dense, white; those on antenna1 area mixed with bright brown; those on vertex $(400-600 \mu)$, dull whitish; those on genal area white mixed with bright brown. Hairs on dorsum of thorax $(400-600 \mu)$, dull whitish; those on mesepisternum white below, duller above; legs with white hairs. Hairs on metasomal terga short and sparse, those on $\mathrm{T}_{1}(300 \mu)$, whitish at basal area; $\mathrm{T}_{2-4}$ with white hair bands lateroapically; $\mathrm{S}_{2-5}$ with not well-formed subapical fimbriae.

Structure: Head: HL / HW = 0.77. HW : MsW : MtW = $2.6: 2.2: 2.2$. Vertex densely tessellate to roughened. OOD : $\mathrm{POD}: \mathrm{OCD}=0.6: 0.4: 0.2 . \mathrm{FL}_{1}=\mathrm{FL}_{2}, \mathrm{FL}_{1}$ slender toward base, $\mathrm{FL}_{2}$ longer than broad. Eyes with inner margins slightly converging toward mandibles. Clypeus convex medially, surface densely shagreening with coarse PP, CPL $=0.7 \mathrm{~mm}$. Process of labrum moderate, broad and short, the ratio about $4: 1$, entire at apex. Lower paraocular area as in clypeus. Malar space linear. Genal area broader than eye, GW : $\mathrm{EW}=0.8: 0.6$, surface densely tessellate with obscure PP. Mesosoma: Pronotum with distinct humeral angle and ridge, lateral surface with slanting rugulae behind ridge, the rest part densely tessellate. Mesoscutum finely shagreened. Scutellum finely tessellate anteriorly, densely tessellate posteriorly. Propodeal enclosure roughened 

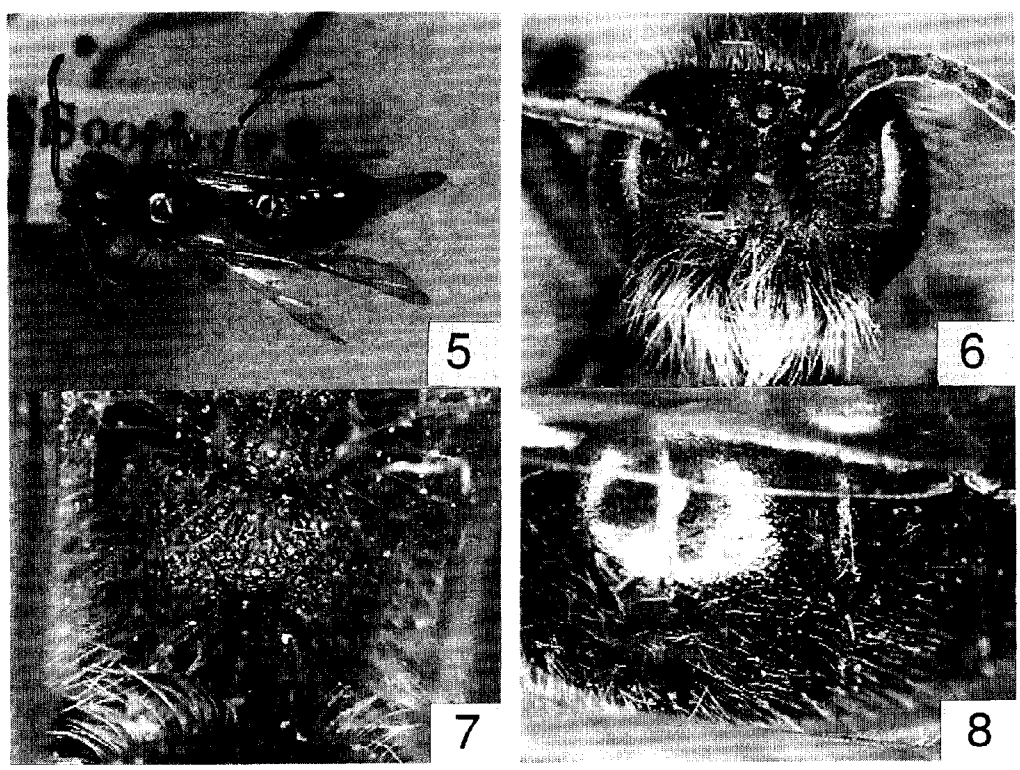

Figs. 5-8. Andrena (Leucandrena) delicatula Cockerell, 5: dorsal view of the whole body; 6: head in frontal view; 7: propodeum; 8: metasomal terga.

with transverse rugulae apically; dorsal face roughened, but weaker than in enclosure. Mesepisternum shagreened. Legs normal. Metasoma: Metasomal terga weakly tessellate. shiny with microscopic fine PP; posterior depressions of terga well indicated. Fraud pygidial plate appearing. $S_{2-5}$ smooth and shiny, nearly impunctate.

Type material examined: Holotype male, Soochou, China (N. Gist Gee, 121), No. 23 187, U. S. N. M.

Remarks: We found it also distributed in Shanghai and Zhejiang Province, China and the female is Andrena (Simandrena) koma Hirashima. This species can be separated from Andrenamelanospila Cockerell by the more tessellated clypeus, the broader process of labrum and the rugulosed propodeal enclosure basally in both sexes.

Distribution: China (Shanghai, Zhejiang Prov.); Korea (southern and central Korea).

Floral record: China: Rubus hirsutus.

Flight records: Female: late April to late May. Male: late March to mid April.

\section{Andrena (Taeniandrena) callopyrrha Cockerell}

(Figs. 9-12)

Andrena callopyrrha Cockerell, 1929, Entomologist, 62: 205 [female, China]; Cockerell. 193 1, Amer. Mus, Nov., (452): 3 [male, China]; Yasumatsu, 1941, Peking nat. Hist. Bull., 15: 274 [in list].

Redescription of the type: Female: BL $10.5 \mathrm{~mm}$, WL $8.0 \mathrm{~mm}$. 
Color: Flagellum dark reddish brown beneath except $\mathrm{FL}_{1}$ yellow basally; mandible with apical third reddened; wing membrane subhyaline, veins and pterostigma yellowish brown; legs reddish brown, tibial spurs ochraceous; posterior depressions of metasomal terga reddish brown.

Pubescence: Hairs on head yellow except antennal area reddish yellow; those on clypeus short $(250-500 \mu)$, dense basally, scanty apically; those on vertex short $(300 \mu)$. dense; facial fovea brown. Hairs on thorax reddish yellow except mesepisternum yellowish; those on mesoscutum and scutellum short $(200 \mu)$, those on metanotum dense: propodeal corbicula moderately developed, with long dorsal fringes, interior with sparse simple hairs; trochanteral floccus perfect, yellowish; femoral floccus dense: tibial scopa well developed, golden yellow, composed of long, simple hairs in front, weakly branched hairs above. Hairs on metasomal terga scanty, $\mathrm{T}_{1}$ with short, lateral white fringes; $T_{2-4}$ with white hair bands, interrupted on $T_{2-3}$; caudal fimbria golden yellow: $\mathrm{S}_{2-}$ 5 with long lateral subapical fimbriae.

Structure: Head: HL / HW $=0.86$. HW $: \mathrm{MsW}: \mathrm{MtW}=3.5: 3.2: 3.2$. Vertex densely tessellate, not roughened. OOD : POD : OCD $=0.7: 0.5: 0.3$. $\mathrm{FL}_{1}=\mathrm{FL}_{2+3}$, $\mathrm{FL}_{2}=\mathrm{FL} 3, \mathrm{FL}_{2}$ as long as broad. Eyes with inner margins subparalleled. Facial fovea exceeding below a line at lower margins antennal fossae, broad, FVL $=1.4 \mathrm{~mm}, \mathrm{FVW}=$ $0.6 \mathrm{~mm}$. Facial quadrangle broader than long (about $2.5: 2.3$ ). Clypeus flattened, surface shagreened with obscure PP, median longitudinal impunctate line obscure, $\mathrm{CPL}=1.2$ $\mathrm{mm}$. Process of labrum trapezoidal, broad and short, the ratio about $5: 1$, surface with curved rugulae, shiny medially with apex emarginate; surface below process smooth and shiny with median crista. Lower paraocular area weakly tessellate with crowded $\mathrm{PP}$ o
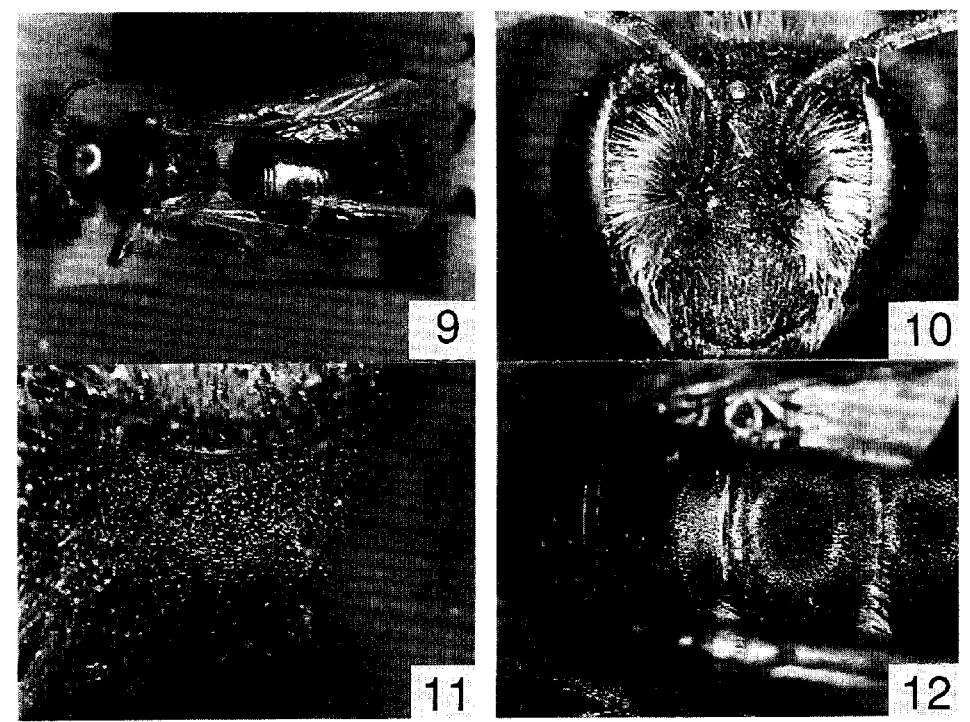

Figs. 9-12. Andrew (Taeniandrena) callopyrrha Cockerell, 9: dorsal view of the whole body; 10: head in frontal view; 11: propodeum; 12: metasomal terga. 
$20 \mu$, IS c 0.5 . Malar space rather short, about one-sixth as long as broad. Genal area as broad as eye, $\mathrm{GW}: \mathrm{EW}=0.8: 0.8$, surface finely shagreened posteriorly, smooth and shiny near eye. Mesosoma: Pronotum without humeral angle and ridge, surface shagreened. Mesoscutum weakly tessellate and shiny except shagreened anteriorly and laterally, with $\mathrm{PP} \phi 20 \mu$, IS $=0.5-1$. Scutellum as in mesoscutum. but PP sparser. Propodeal enclosure ill defined, roughened all over; dorsal face rugosed by coarse punctation. Mesepisternum weakly roughened anteriorly, densely tessellate posteriorly. Middle basitarsus as broad as hind basitarsus. Metasoma: metasomal terga finely tessellate; $T_{1}$ nearly impunctate basally, weakly punctate on subapical area; $\mathrm{T}_{2-4}$ with dense minute PP, IS =1, sparse on apical area; posterior depressions of metasomal terga well indicated. Pygidial plate V-shaped, without raised triangular area. $\mathrm{S}_{2-5}$ finely tessellate as in terga.

Type material examined: Holotype female, Tsinan, China, No. 553 16, U. S. N. M.

Remarks: This species is similar to Andrena wilkella (Kirby). It can be separated from wilkella by the propodeal enclosure roughened all over, the clypeus densely tessellate without obvious PP and median impunctate space and less tessellation on dorsum of thorax in female.

Distribution: China (Shandong Prov.).

Floral record: Not available.

Flight record: Female: early April.

\section{Andrena(Melandrena) crassepunctata Cockerell}

(Figs. 13- 16)

Andrena crussepunctata Cockerell, 1931, Amer. Mus. Nov., (466): 10- 11 [female, China]; Yasumatsu, 1941, Peking nat. Hist. Bull., 15: 275 [in list]; Kim, 1970. Ill. Encycl. Faun. Fl. Korea, 1 1(3): 659-660 [Korea].

Andrenu crassipunctatu [sic]: Wu, 1965, Econ. Insects China IX, Apoidea: 32 [China]. Andrenu (Gymnandrena) crussepunctata: Hirashima, 1957, Mushi. 30: 63 [China, Korea].

Andrena (Gymnundrena) crusspunctata [sic]: Kim et al., 1990, Ent. Res. Bull., 16: 2-3 [Korea]; Shin et al., 1994, Check List Insects Kor., 266 [in list].

Redescription of the type: Female: BL $13.2 \mathrm{~mm}$, WL $11.4 \mathrm{~mm}$.

Color: Flagellum yellowish brown beneath; mandible reddened apically; wing membrane subhyaline, dark brown, paler at apex, veins black and pterostigma dark brown with black margin; tibial spurs reddened; posterior depressions of metasomal terga dark reddish brown.

Pubescence: Hairs on head and thorax dense; those on clypeus long (600-700 $\mu$ ). black; those on antenna1 and genal areas black; those on vertex moderately long $(500 \mu)$. black; facial fovea brown. Hairs on dorsum of thorax long (700-800 $\mu$ ), yellow; those on mesepisternum black below, yellow above; propodeal corbicula well developed with dense hairs, brown with internal simple hairs; trochanteral floccus perfect. brown; femoral floccus dense; tibial scopal hairs long, simple, brown. Hairs on metasomal terga scanty, without hair band; caudal fimbria black; $\mathrm{S}_{2-5}$ with complete black subapical fimbriae. 

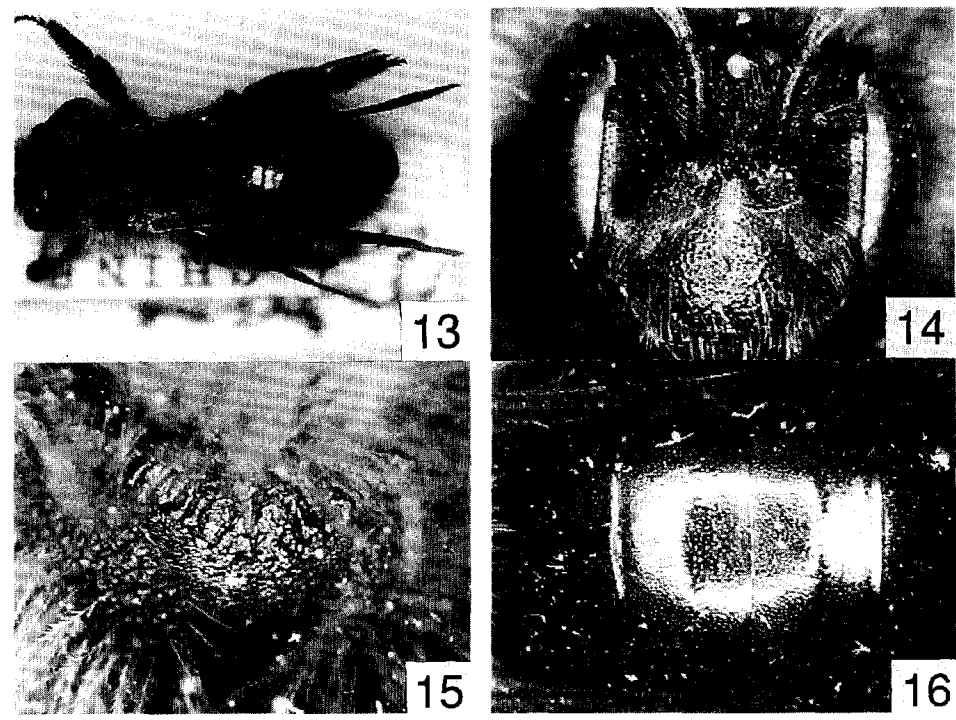

Figs. 13-16. Andrena (Melandrena) crassepunctutu Cockerell, 13: dorsal view of the whole body; 14: head in frontal view; 15: propodeum; 16: metasomal terga.

Structure: Head: HL / HW $=0.87$. HW $: \mathrm{MsW}: \mathrm{MtW}=3.9: 4.3: 5.0$. Vertex densely tessellate to roughened. OOD : $\mathrm{POD}: \mathrm{OCD}=0.8: 0.5: 0.4$. FL, slightly shorter than $\mathrm{FL}_{2+3}, \mathrm{FL}_{2}$ subequal to FL3. Eyes with inner margins paralleled. Facial fovea deep, separated from inner margin of eye by broad punctate space, far exceeding below a line at lower margins antennal fossae, FVL $=1.7 \mathrm{~mm}, \mathrm{FVW}=0.4 \mathrm{~mm}$. Facial quadrangle broader than long (about $2.9: 2.7$ ). Clypeus well convex, surface with rugoso-punctate, with $\mathrm{PP} \phi 40 \mu$, IS $<0.5$, smaller at lateral angle, with median longitudinal impunctate space, $\mathrm{CPL}=1.5 \mathrm{~mm}$. Process of labrum trapezoidal, large, entire apically. Lower paraocular area finely tessellate with $\mathrm{PP} \phi 20 \mu$, IS c 1 . Malar space nearly linear. Genal area broader than eye, $\mathrm{GW}: \mathrm{EW}=1.2: 0.8$, surface densely tessellate posteriorly. smooth and shiny with sparse PP near eye. Mesosoma: Pronotum without humeral angle and ridge, surface shagreened with close PP. Mesoscutum and scutellum dulled by coarse tessellation with crowded $\mathrm{PP} \phi 20 \mu$, IS $<0.5$. Propbdeal enclosure wrinkled at basal half. densely tessellate apically; dorsal face roughened by coarse punctation. Mesepisternum shagreened anteriorly with $\mathrm{PP} \phi 30 \mu$, IS $=1$, densely tessellate posteriorly. Metasoma: Metasomal terga weakly tessellate, feebly shiny; $\mathrm{T}_{1}$ with $\mathrm{PP} \phi 10-20 \mu$, IS $<1$ laterally and apically, sparser and irregular in distribution mediobasally; $\mathrm{T}_{2-4}$ with $\operatorname{PP} \phi 20 \mu$, IS $<0.5$ laterally, sparser medially and apically; posterior depression on $T_{2}$ narrow. on $T_{3-4}$ broad, well indicated. Pygidial plate large, U-shaped, with raised triangular area. $\mathrm{S}_{2-5}$ densely tessellate with crowded PP except apical areas smooth and shiny, impunctate.

Type material examined: Holotype female, Zô-Zè, Kiang-Sou, Chine, April 17. 1930 (Pie1 No. 36), AMNH. 
Remarks: This species is similar to Andrena thoracica sinensis Cockerell, it is separated from thoracica sinensis by the clypeus with distinct median impunctate space, the entire process of labrum, $\mathrm{FL}_{1}$ shorter than $\mathrm{FL}_{2+3}$ in female.

Distribution: China (Beijing, Heilongjiang, Jilin, Liaoning, Hebei, Shandong, Jiangsu, Zhejiang Provs.); Korea (Kyonggi Do, Kangwon Do, Cheju Do).

Floral record: China: Medicago sativa $\mathrm{L}$.

Flight records: Female: mid April to mid May.

\section{Acknowledgements}

We are grateful to Dr. R. McGinley of the National Museum of Natural History, Smithsonian Institution, Washington D. C. and Dr. J. G. Rozen of the American Museum of Natural History, New York for sending useful materials on loan.

\section{References}

Cockerell, T. D. A., 1911. Bees in the collection of the United States National Museum. 2. Proc.U.S. nat. Mus., 40: 241-264.

Cockerell, T. D. A., 1918. Descriptions and records of bees LXXXII. Ann. Mag.nat. Hist., (9)2: 476-482.

Cockerell, T. D. A., 1929. Red-haired bees from China. Entomologist, 62: 205-207.

Cockerell, T. D. A., 1931a. Some bees collected by Professor Jacot in China. Amer. Mus. Novitates, (452): l-3.

Cockerell, T. D. A., 1931b. Bees collected by the Reverend 0. Piel in China. Amer. Mus. Novitates, (466): 1-1 6.

Hirashima, Y., 1962-1966. Systematic and biological studies of the family Andrenidae of Japan (Hymenoptera, Apoidea) Part II. Systematics 1-7. J.Fac. Agr., Kyushu Univ., 12: 117-154, 241-263; 13: 39-69, 71-97, 461-491, 493-517; 14: 89-131.

Perez, J., 1905. Hyménoptères recueillis dans le Japon central, par M. Harmand. Ministre plenipotentiaire de France à Tokio. Bull. Mus.d'Hist. Naturelle, Paris. 1905: 33-35. 